\title{
Analysis of static response of RC beams with NSM CFRP/GFRP rods
}

\author{
R. Capozucca, E. Magagnini, M.V. Vecchietti \\ Struct.Section DICEA, Università Politecnica delle Marche, Ancona, Italy \\ r.capozucca@staff.univpm.it,e.magagnini@staff.univpm.it,m.v.vecchietti@pm.univpm.it
}

\begin{abstract}
In this paper experimental results of investigation on reinforced concrete (RC) beams strengthened with the near surface method (NSM) are analyzed considering the response under bending tests on two beams. One of the RC beams was damaged by bending until the yield of reinforcement and successively strengthened with carbon fiber polymer (CFRP) rod, while the second beam was strengthened with glass-FRP rod. Both the beams have been subjected to bending tests until failure. Experimental diagrams and discussion on static response are presented in the paper. It also places a particular emphasis on the non-linear response of RC sections strengthened with CFRP and GFRP rods under bending moment beyond the first elastic behavior.
\end{abstract}

KEYWORDS. RC beams; NSM; CFRP-GFRP rod; Static test.

\section{OPEN ACCESS}

Citation: R. Capozucca, E. Magagnini, M.V. Vecchietti, Analysis of static response of RC beams with NSM CFRP/GFRP rods, Frattura ed Integrità Strutturale, 58 (2021) 402-415.

Received: 26.08 .2021

Accepted: 03.09 .2021

Published: 01.10.2021

Copyright: (C) 2021 This is an open access article under the terms of the CC-BY 4.0, which permits unrestricted use, distribution, and reproduction in any medium, provided the original author and source are credited.

\section{INTRODUCTION}

$\mathrm{T}$ he damage of reinforced concrete (RC) structures both for civil building and bridges is an important duty of structural engineering. Rehabilitation of structures requests innovative techniques with new material [1-4]. In the last decades the use of fiber reinforced polymers (FRPs) has been growing and, in general, two methods of strengthening have been adopted. First it was the FRP strips or laminates glued to surface of RC beams [2,3]; this technique may be indicated as external bonded (EB) strengthening. It appears an available method to strengthen RC beams, but it may be loss validity for impact or due to fire because the FRP strips or laminate are non-sufficiently protected. A second technique is the near surface mounted (NSM) that foresees to insert FRP rods in grooves on the concrete cover [4-10]. This technique appears available in many experimental studies thought the bond between concrete and FRP rods is a yet open problem to analyze [10-13]. In fact, the maintaining of bond is the most important condition that must be monitored in the beams strengthened with NSM FRP rods [14-18]. Experimental works have been developed by researchers to analyze the static $[14,15]$ and vibration responses of strengthened RC beams in real scale or in small scale [19-22]. Other aspects that may influence the response under loading are: shape of FRP rods, circular or rectangular; distance between rods and surface of grooves; roughness of FRP rods' surface; tensile strength of FRP rods [23-25]. In literature, investigations on the behavior of RC beams strengthened with CFRP and GFRP rod are present [26-30] also considering new methods [30]; further Codes of Practice [31] have been developed and they may be utilized by engineers. Unfortunately, many aspects of NSM technique 
must be develop more and other experiments are necessary to define modelling and responses both in service and ultimate conditions.

This paper deals with the investigation by static tests on RC beams strengthened both with CFRP and GFRP rods. A couple of beams in real scale with one RC beam subjected to bending tests at different damage degree is analyzed: one beam, damaged by bending and strengthened with NSM Carbon-FRP rod, has been tested; another one RC beam strengthened by NSM GFRP rod, has been experimentally studied. Static results are shown and discussed below considering the nonlinear behavior of RC beams under loading.

\section{EXPERIMENTAL BENDING TESTS}

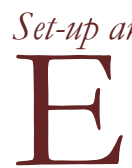

and strengthening material

xperimental tests were carried out on two RC beams, B1 and B2, with a cross-section of $120 \cdot 160 \mathrm{~mm}$ and length of $2200 \mathrm{~mm}$, the steel reinforcement consisted of four longitudinal steel bars of $10 \mathrm{~mm}$ diameter and stirrups of 6 $\mathrm{mm}$ diameter. A groove of $20.20 \mathrm{~mm}$ was created at the bottom of each beam to locate an NSM reinforcement bar. After static tests, beam B1 was strengthened with a CFRP rod measuring $9.7 \mathrm{~mm}$ in diameter and $2000 \mathrm{~mm}$ in length, while beam B2 was strengthened with a GFRP rod of $9.5 \mathrm{~mm}$ diameter and $2000 \mathrm{~mm}$ length. Fig. 1 depicts geometric configuration of the specimens. The two beams tested in laboratory were characterized by concrete with a tested average cylinder compressive strength equal to $f_{c}=44.31 \mathrm{MPa}$ and Young's modulus $E_{c}=34492 \mathrm{MPa}$; steel bars with a yielding stress equal to $f_{y}=450 \mathrm{MPa}$ and Young's modulus $E_{s}=210000 \mathrm{MPa}$.

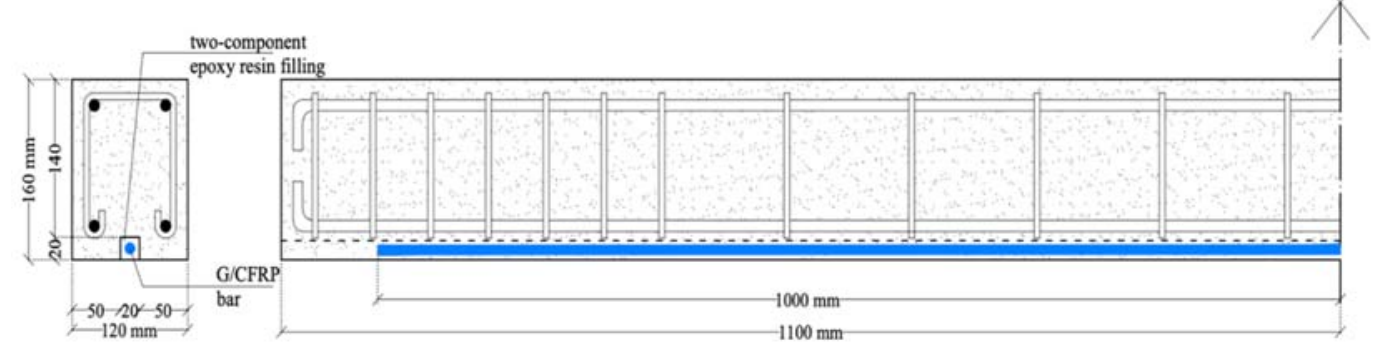

Figure 1: Beam model with steel reinforcing and NSM FRP rod: geometrical features.

\begin{tabular}{ccccc}
\hline Specimens & $\begin{array}{c}\text { Diameter, } d \\
{[\mathrm{~mm}]}\end{array}$ & $\begin{array}{c}\text { Section Area, } A_{\text {CFRP }} \\
{\left[\mathrm{mm}^{2}\right]}\end{array}$ & $\begin{array}{c}\text { Tensile strength, } f \\
{[\mathrm{MPa}]}\end{array}$ & $\begin{array}{c}\text { Young's modulus, } E \\
{[\mathrm{MPa}]}\end{array}$ \\
CFRP rod & 9.7 & 73.90 & 2000 & 155000 \\
GFRP rod & 9.53 & 71.26 & 760 & 40800 \\
\hline
\end{tabular}

Table 1: Results of tensile tests on FRP rods.

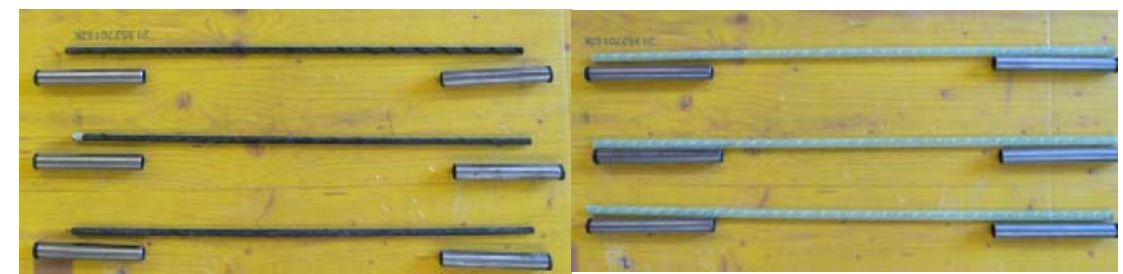

(a)

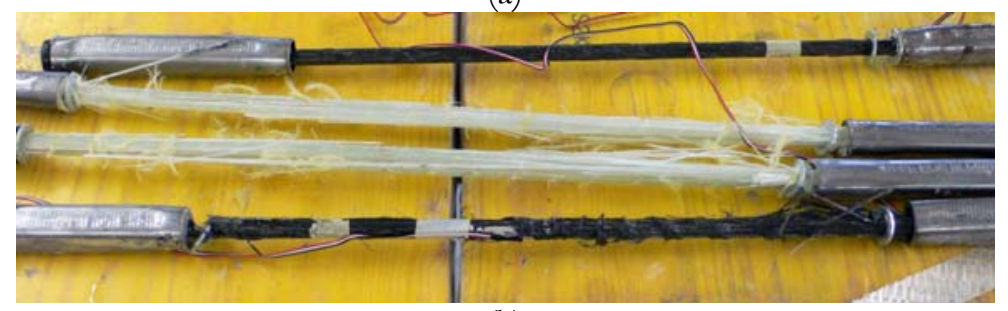

(b)

Figure 2: (a) Specimens of CFRP and GFRP rods for tensile tests; (b) failure of specimens after tensile tests. 
Company MAPEI produced the CFRP and GFRP rods used in this research. Tensile tests on three specimens for each type of fiber were used to determine the mechanical and geometrical properties of the C-GFRP rods (Fig. 2a); all the samples' failures were in the XGM category - Explosive, Gage, Middle - as defined by ASTM D-3039 [32] (Fig. 2b). Main results obtained by tensile tests are summarized in Tab. 1. A two-component epoxy structural adhesive $\left(E_{r e s}=5130 \mathrm{MPa}\right)$ was adopted for the bonding of the FRP rod to the concrete surfaces into the notch.

\section{Static response of beams damaged and strengthened}

The first phase of static bending tests involves experimentation on the un-strengthened RC beam B1. The apparatus was design to reproduce a simply supported condition with hinge restraints at the extremities, as presented in Fig. 3.

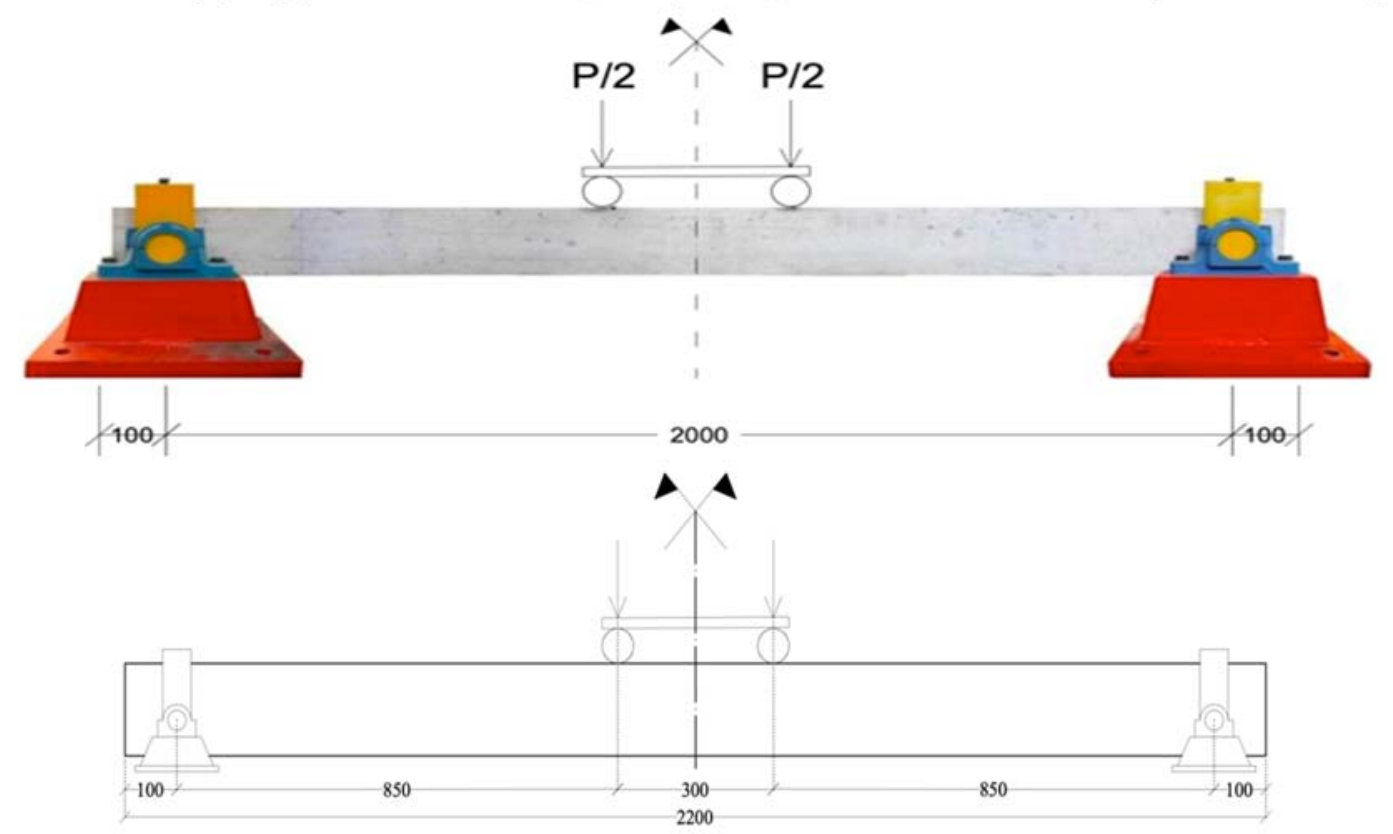

Figure 3: Experimental apparatus for static bending tests.

The external load was applied in two points placed at a distance of $300 \mathrm{~mm}$ through vertical jacks; the compressed concrete's and the tensile steel's strains were monitored using electronic strain gauges positioned at the centreline (Fig. 4). The beam's deflection was recorded by a Linear Inductive Displacement Trasducer (LVDT) applied at the midspan section. The beam without strengthening was subjected to static tests using an increasing bending loading path. Three cycles of loading were adopted. For each cycle of loading $\mathrm{P}_{\mathrm{i}}$, a damage level $\mathrm{D}_{\mathrm{i}}$ with $\mathrm{i}=1,2,3$ was identified, as shown in Tab. 2. Results of static bending tests, in terms of deflection, concrete and steel strain and curvature, are summarized in Tab. 2. The experimental diagrams displayed in Fig. 5 were developed by measurements taken in terms of deflection and strains at the midspan of RC beam B1. Therefore, it is possible to characterize the static behavior of beam B1 before the application of NSM CFRP strengthening, based on these data.

After reaching a consistent state of concrete's cracking, a CFRP circular rod was positioned in the notched and then it was filled by adhesive epoxy resin. The strengthened beam B1 was subjected once again to cyclic bending loading. The first three damage levels were the same as for the previous unreinforced case. Two additional cycles of loading, $\mathrm{D}_{4}$ and $\mathrm{D}_{5}$, were adopted, for a total of five degrees of damage.

\begin{tabular}{cccccc}
\hline $\begin{array}{c}\text { Damage } \\
\text { steps }\end{array}$ & $\begin{array}{c}\text { Load, P } \\
{[\mathrm{kN}]}\end{array}$ & $\begin{array}{c}\text { Deflection at } \\
\text { midspan, } \delta \\
{[\mathrm{mm}]}\end{array}$ & $\begin{array}{c}\text { Strain at } \\
\text { compressive } \\
\text { concrete, } \\
\varepsilon_{\mathrm{c}}(\% \mathrm{o})\end{array}$ & $\begin{array}{c}\text { Strain at steel } \\
\text { reinforcement } \\
\text { (at intrados), } \\
\varepsilon_{\mathrm{s}}(\% \mathrm{o})\end{array}$ & $\begin{array}{c}\text { Curvature at } \\
\text { midspan section, } \\
\chi\left(10^{-5}\right)\end{array}$ \\
$\mathrm{D}_{1}$ & 4.00 & 1.65 & 0.21 & 0.85 & 0.81 \\
$\mathrm{D}_{2}$ & 8.00 & 4.67 & 0.50 & 1.64 & 1.64 \\
$\mathrm{D}_{3}$ & 16.00 & 11.38 & 0.94 & 3.10 & 3.11 \\
\hline
\end{tabular}

Table 2: Experimental results obtained for un-strengthened beam B1. 
After the fifth damage level, the strengthened beam B1 was subjected to increasing load until the collapse. The maximum load reached during test, that lead to the specimen's failure, was equal to $P_{u}=49.06 \mathrm{kN}$.

As previously described, the recording of the strains achieved during the test, has been entrusted to one strain gauges placed on the CFRP rod, as shown in Fig. 5. Tab. 3 contains a summary of the main data acquired from the instrumentation used for each loading step and the curvature at the midspan section evaluated for the strengthened beam B1.

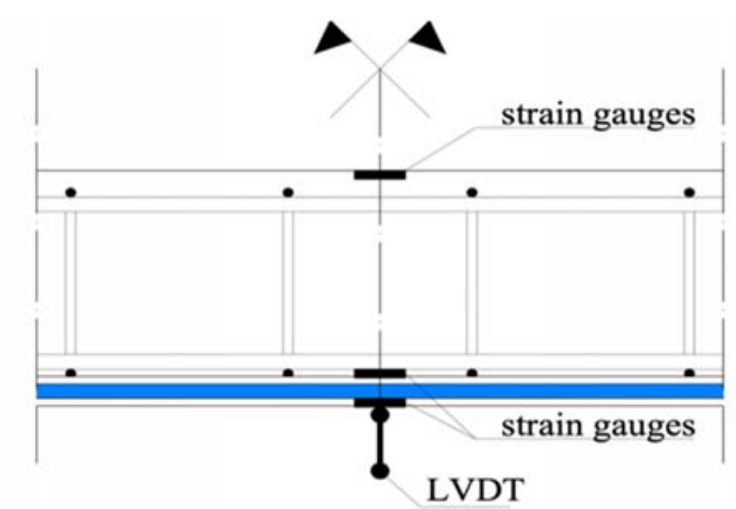

Figure 5: Instruments for strain and displacement monitoring at the midspan.

\begin{tabular}{|c|c|c|c|c|c|c|}
\hline $\begin{array}{c}\text { Damage } \\
\text { steps }\end{array}$ & $\begin{array}{c}\text { Load, P } \\
{[\mathrm{kN}]}\end{array}$ & $\begin{array}{c}\text { Deflection at } \\
\text { midspan, } \delta \\
{[\mathrm{mm}]}\end{array}$ & $\begin{array}{l}\text { Strain at } \\
\text { compressive } \\
\text { concrete, } \\
\varepsilon_{\mathrm{c}}(\% 0)\end{array}$ & $\begin{array}{l}\text { Strain at steel } \\
\text { reinforcement } \\
\text { (at intrados), } \\
\varepsilon_{\mathrm{s}}(\% 0)\end{array}$ & $\begin{array}{c}\text { Strain at CFRP } \\
\text { rod, } \\
\varepsilon_{\text {CFRP }}(\%)\end{array}$ & $\begin{array}{c}\text { Curvature at } \\
\text { midspan } \\
\text { section*, } \\
\chi\left(10^{-5}\right)\end{array}$ \\
\hline $\mathrm{D}_{1}$ & 4.00 & 0.96 & 0.09 & 0.24 & 0.14 & 0.03 \\
\hline $\mathrm{D}_{2}$ & 8.02 & 0.80 & 0.24 & 0.52 & 0.55 & 0.21 \\
\hline $\mathrm{D}_{3}$ & 18.01 & 3.29 & 0.59 & 1.42 & 1.50 & 0.61 \\
\hline $\mathrm{D}_{4}$ & 24.01 & 7.36 & 0.83 & 2.10 & 2.06 & 0.82 \\
\hline $\mathrm{D}_{5}$ & 30.01 & 9.45 & 1.05 & - & 2.73 & 1.12 \\
\hline
\end{tabular}

Table 3: Main results obtained by static bending tests for beam B1 with NSM CFRP.

* Curvature evaluated from deformation on compressive edge and CFRP bar.

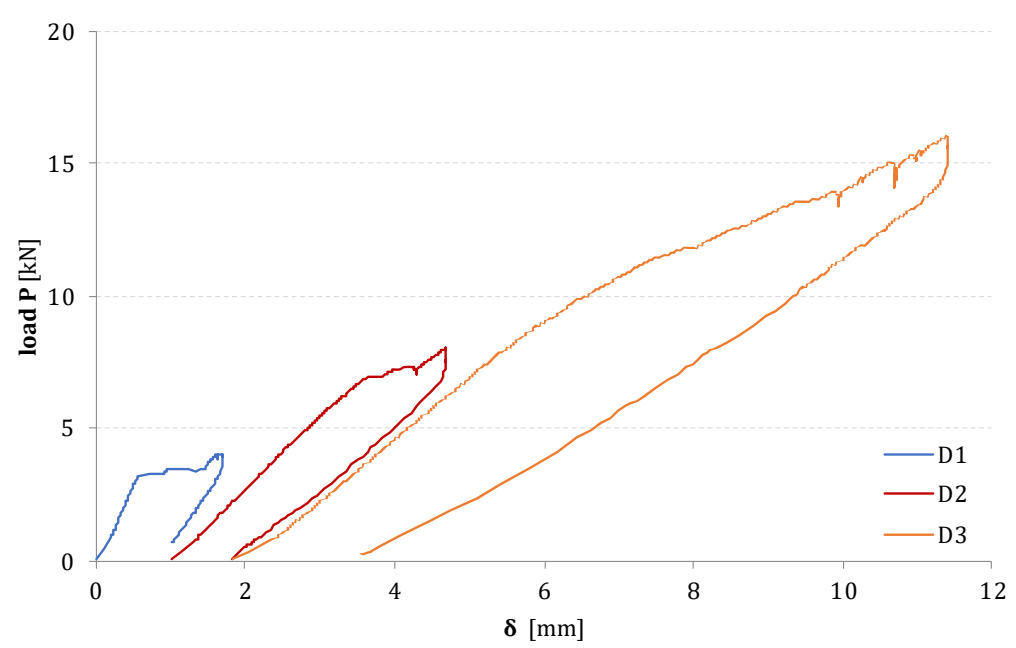

(a) 


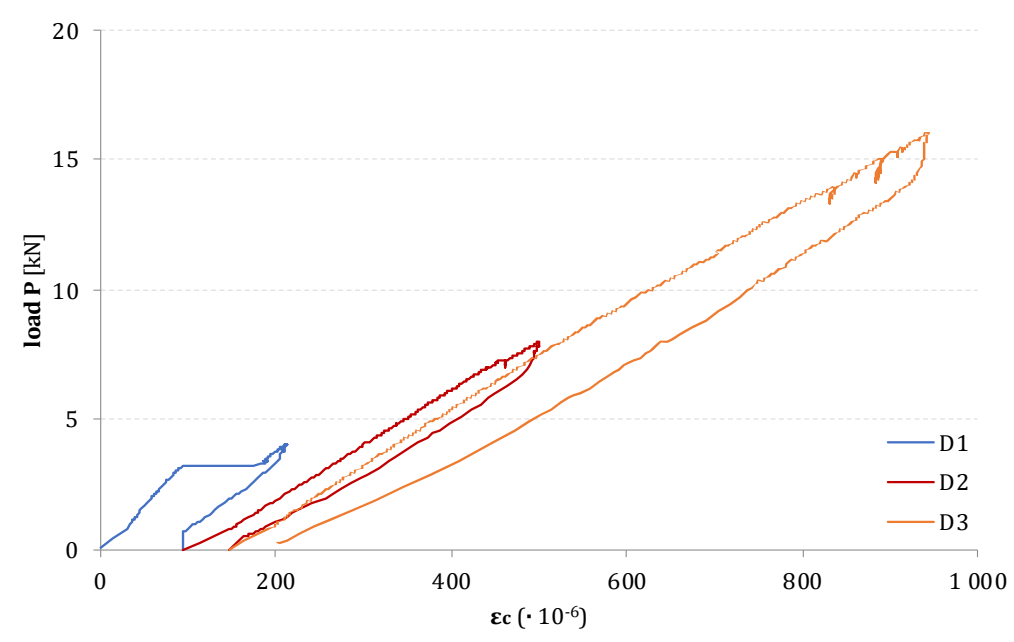

(b)

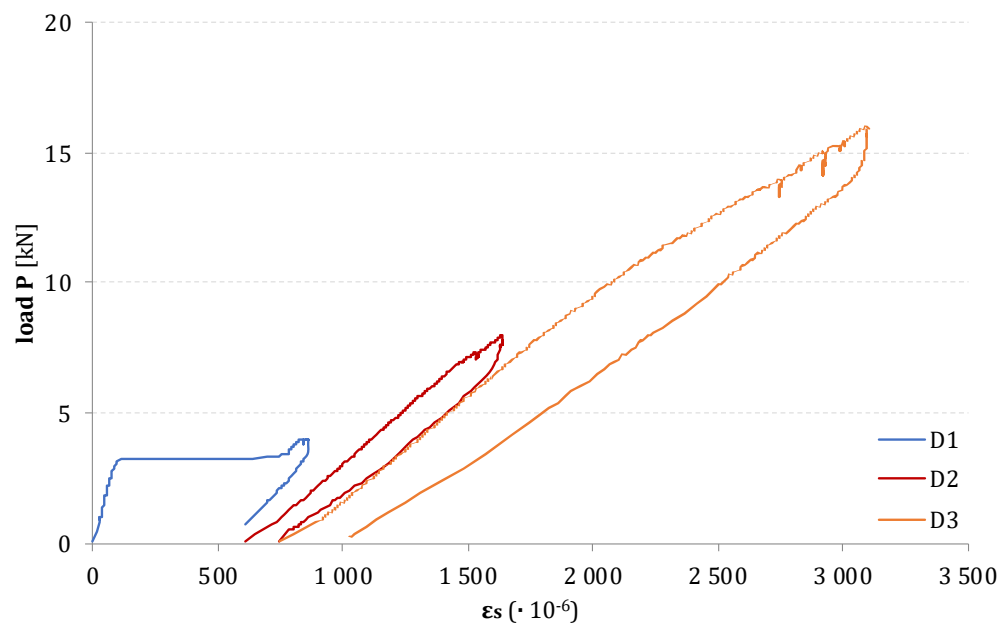

(c)

Figure 5: Diagrams (a) load, P, vs deflection, $\delta$; (b) load, P, vs strain, $\varepsilon_{\mathrm{c}}$, at the edge of compressive concrete and (c) load, P, vs strain of tensile steel, $\varepsilon_{\mathrm{s}}-\mathrm{RC}$ beam B1 without strengthening.

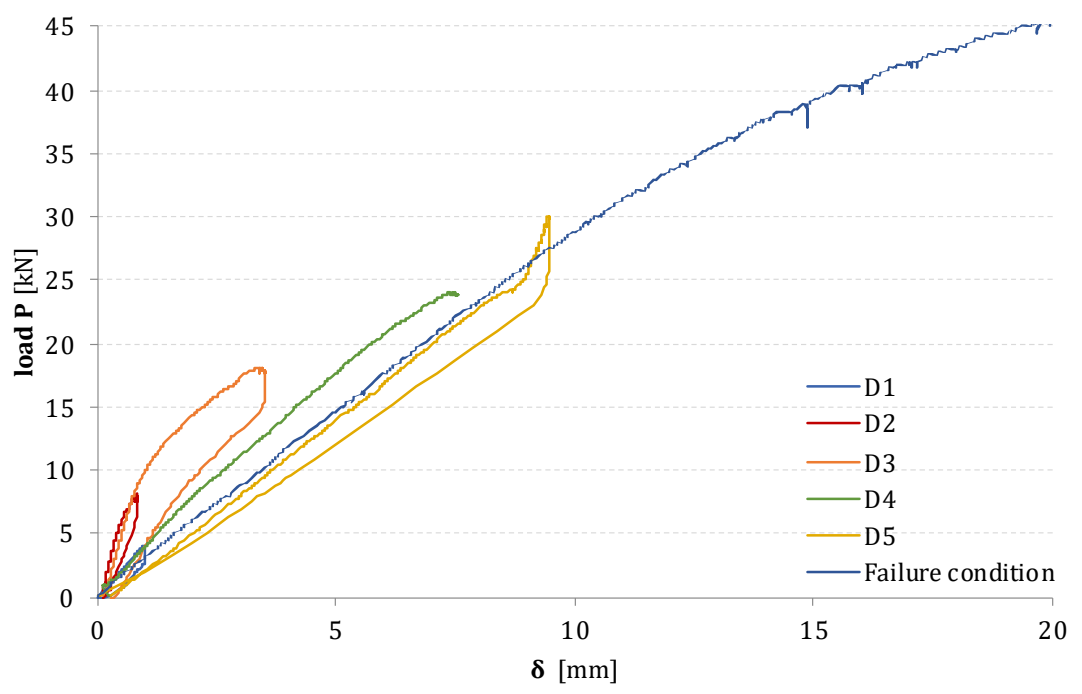

(a) 


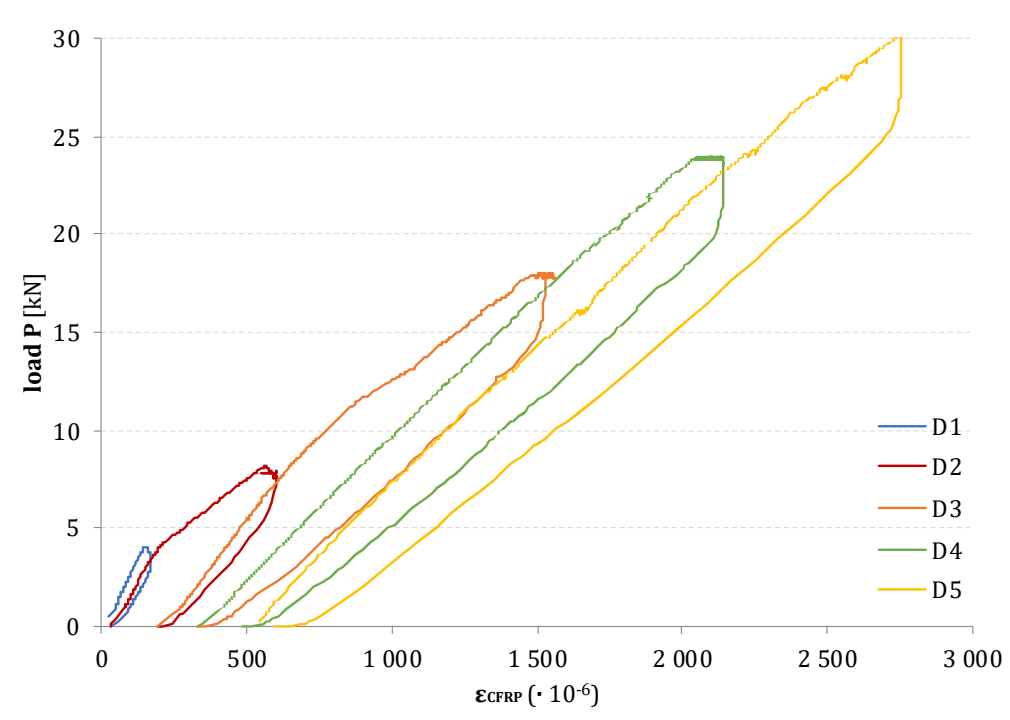

(b)

Figure 6: Diagrams (a) load, P, vs deflection, $\delta$, and (b) load, P, vs strain of CFRP rod, $\varepsilon_{\text {CFRP, }}$ - RC beam B1 with NSM CFRP rod.

In Fig. 7 the diagrams of moment, $M$, versus curvature, $\chi$, refer to the cross-sectional area, obtained by static bending tests are illustrated: the first one is referred to un-strengthened specimen B1, where $\chi$ is calculated from values recorded on compressive concrete edge and on steel bar; the second one is referred to strengthened beam B1, where $\chi$ is obtained from strain values measured on compressive concrete edge and on CFRP rod.

Results of static bending tests obtained for beam with NSM CFRP strengthening are shown in Fig. 6 in term of load deflection $(P-\delta)$ and load - strain of tensile CFRP rod $\left(P-\varepsilon_{C F R P}\right)$ diagrams evaluated at midspan section of beam.

During the tests, the propagation of cracks was also visually observed: after the first load cycle, with $P_{1}=4 \mathrm{kN}$, the cracks on the un-strengthened specimen, was almost absent; when the load was increased, the crack pattern followed the trend of a typical RC beam, with vertical cracks in midspan and oblique cracks nearby the supports, as shown in Fig. 8.

In the NSM CFRP strengthened beam, the crack pattern developed following the fractures occurred during the previous test on the un-strengthened specimen; only for the last two loading cycles the cracks increased in depth and width (Fig. 9). If we analyze the collapse mode of beam B1 strengthened with NSM CFRP, it can be seen that the specimen reached failure for the crushing of compressed concrete and the debonding of the CFRP rod that began at the maximum moment region region and propagated to an extremity of beam. In particular, the debonding between adhesive and the surrounding concrete was recorded at midspan; moving away from the midspan section, also part of concrete cover was interested (Fig. 10).

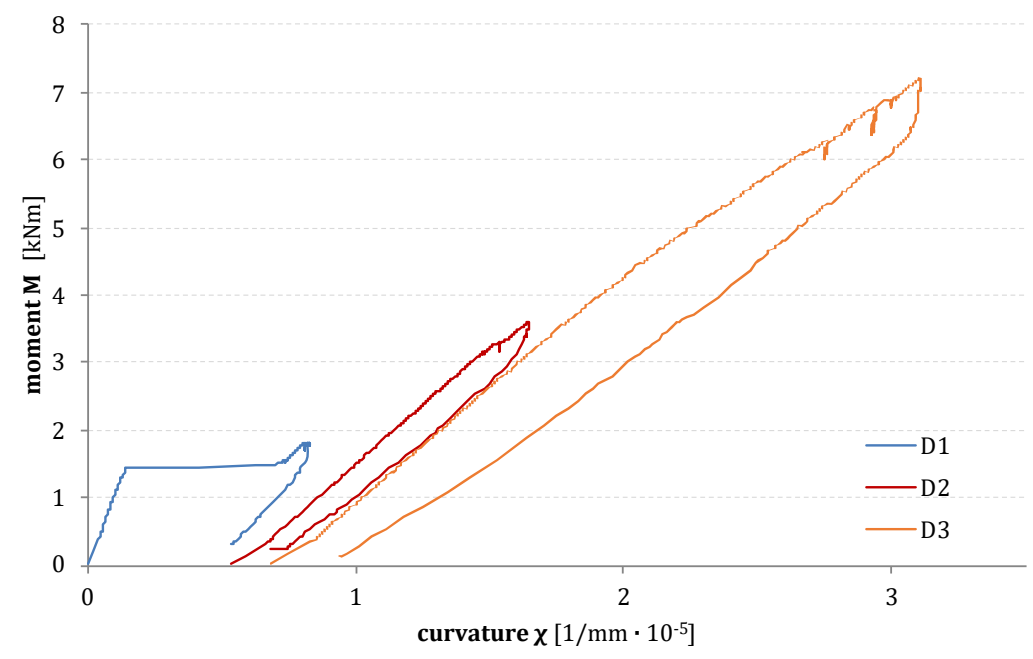

(a) 


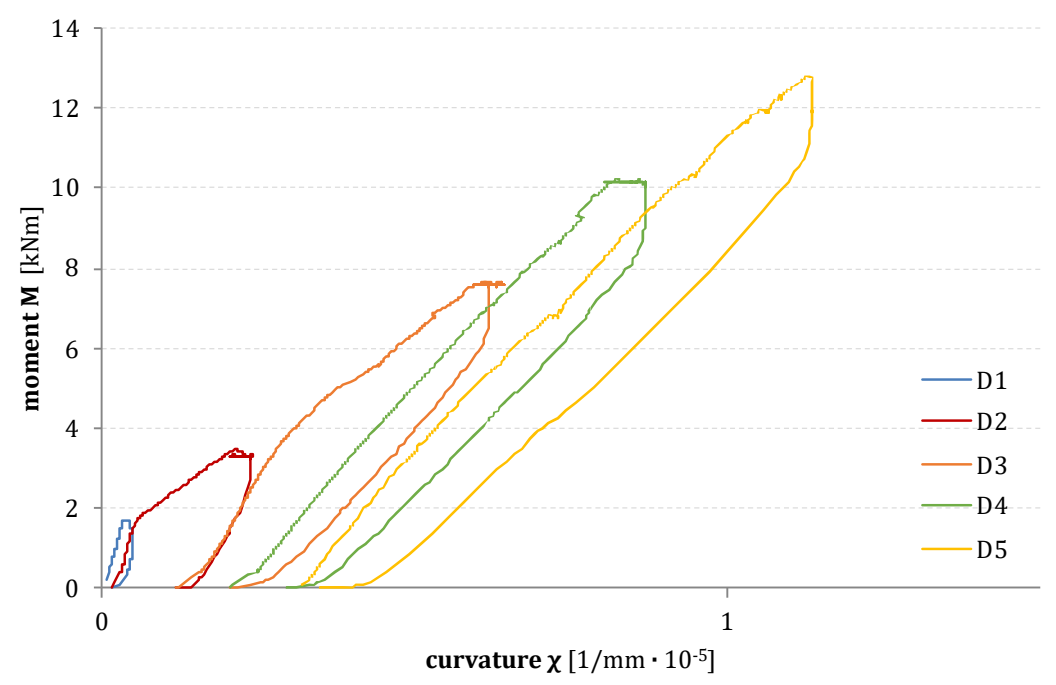

(b)

Figure 7: Diagrams moment, M, vs curvature, $\chi$, evaluated at the midspan section for(a) un-strengthened and (b) NSM CFRP strengthened RC beam B1.

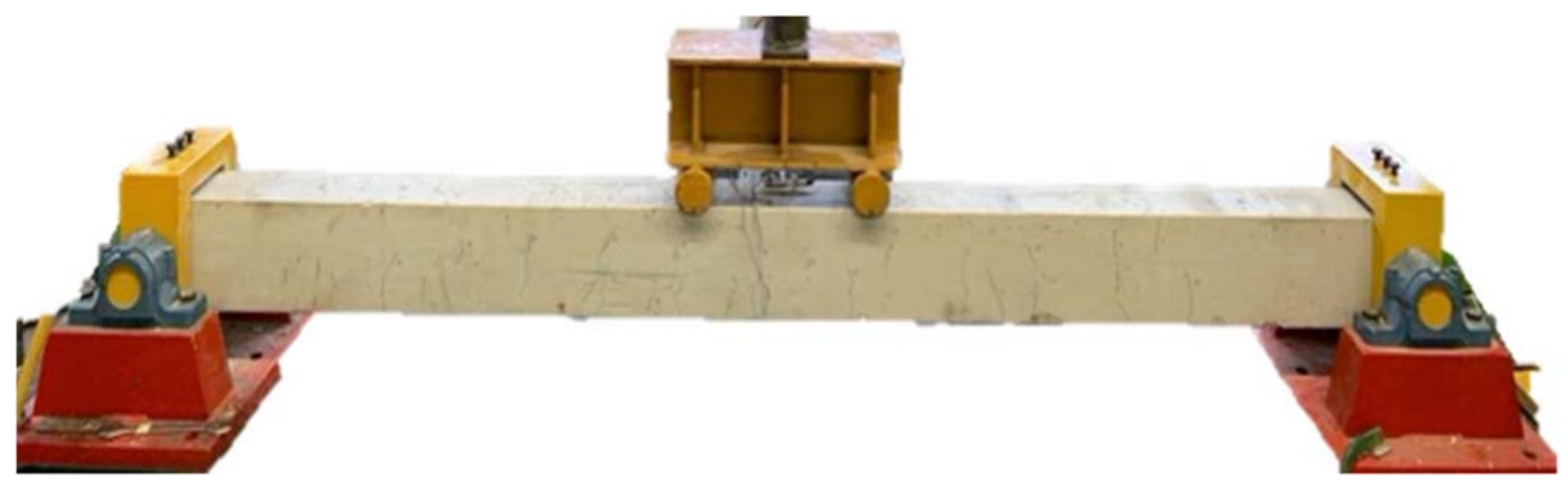

Figure 8: Visualization of cracks by bending loading at damage level $\mathrm{D}_{3}$ for $\mathrm{RC}$ beam $\mathrm{B} 1$ without strengthening.

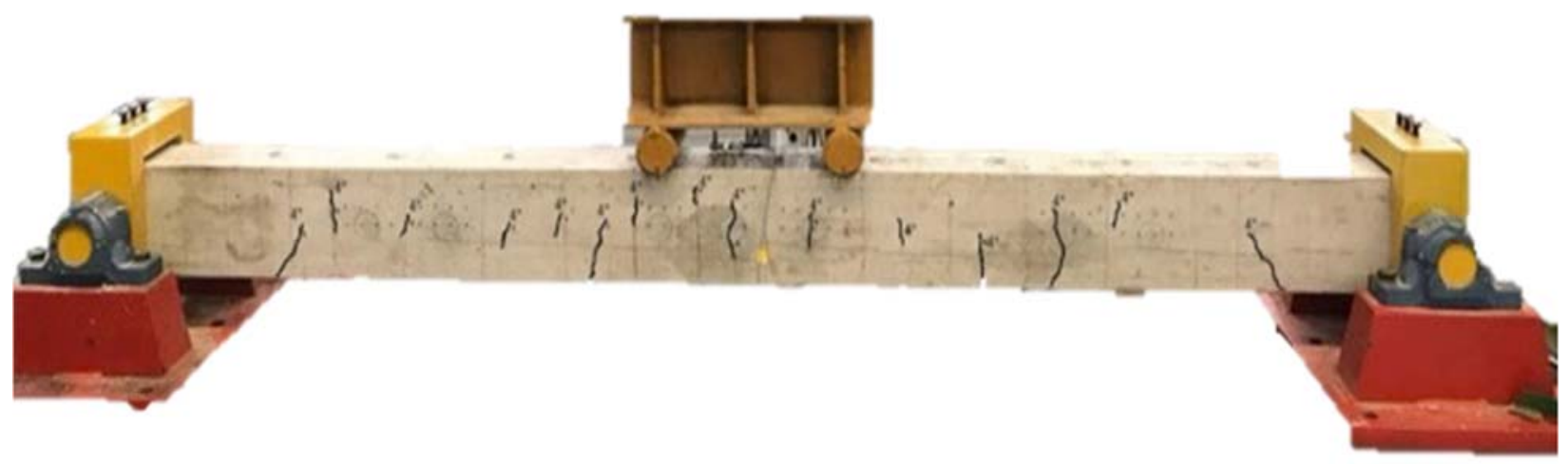

Figure 9: Visualization of cracks by bending loading at damage level $\mathrm{D}_{5}$ for $\mathrm{RC}$ beam $\mathrm{B} 1$ strengthened with NSM CFRP rod. 

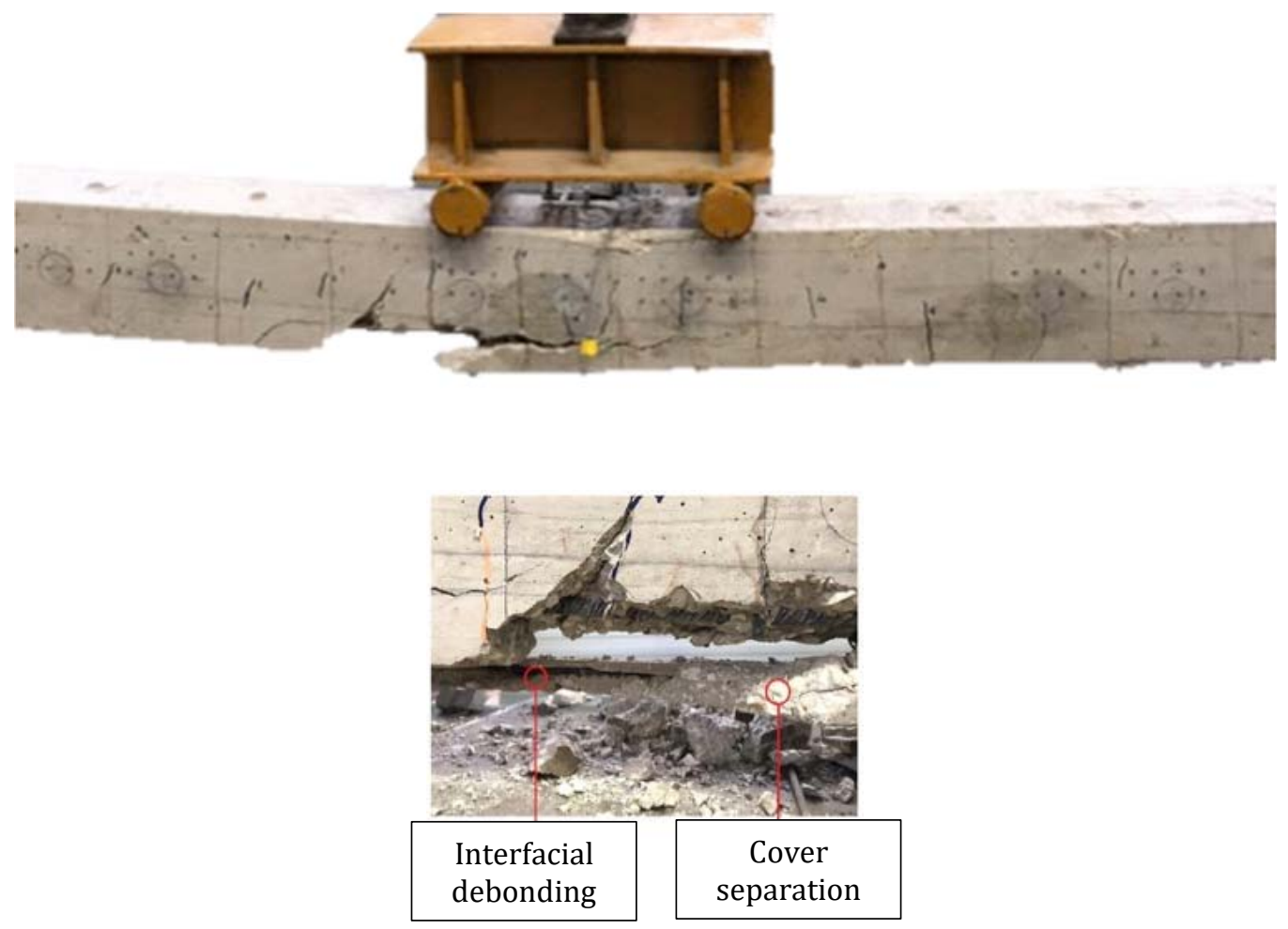

Figure 10: Collapse of beam B1 strengthened with NSM CFRP rod.

Following the same strategy, RC beam B2, strengthened with NSM GFRP rod was tested statically, adopting the same setup and the same instrumentation. Static bending tests were carried out on the beam applying four cycles of bending loading and then increasing the load until the collapse of the sample. In this case as well, the steps of loading were related to the degree of damage $D_{i}$ with $i=1,2,3,4$. Tab. 4 presents the main level of loading adopted durin tests together with the main data achieved from experimentation. Fig. 11 presents the trace of the deflection, $\delta$, recorded at the centerline of beam in relation to the increasing of bending load, $P$; in addition, the development of strain on tensile GFRP rod, $\varepsilon_{\mathrm{GFRP}}$, is traced. The evolution of the curvature, $\chi$, relative to the cross-sectional area and computed from data measured on compressive concrete and GFRP rod, in relation to the increasing of moment, M, is depicted in Fig. 12.

\begin{tabular}{|c|c|c|c|c|c|c|}
\hline $\begin{array}{c}\text { Damage } \\
\text { steps }\end{array}$ & $\begin{array}{c}\text { Load, P } \\
{[\mathrm{kN}]}\end{array}$ & $\begin{array}{c}\text { Deflection at } \\
\text { midspan, } \delta \\
{[\mathrm{mm}]}\end{array}$ & $\begin{array}{l}\text { Strain at } \\
\text { compressive } \\
\text { concrete, } \\
\varepsilon_{\mathrm{c}}(\% 0)\end{array}$ & $\begin{array}{l}\text { Strain at steel } \\
\text { reinforcement } \\
\text { (at intrados), } \\
\varepsilon_{\mathrm{s}}(\% 0)\end{array}$ & $\begin{array}{c}\text { Strain at GFRP } \\
\text { rod, } \\
\varepsilon_{G F R P}(\% 0)\end{array}$ & $\begin{array}{l}\text { Curvature at } \\
\text { midspan } \\
\text { section* } \\
\chi\left(10^{-5}\right)\end{array}$ \\
\hline $\mathrm{D}_{1}$ & 4.00 & 1.87 & 0.14 & 0.39 & 0.34 & 0.13 \\
\hline $\mathrm{D}_{2}$ & 8.06 & 3.69 & 0.30 & 0.79 & 0.72 & 0.28 \\
\hline $\mathrm{D}_{3}$ & 16.02 & 7.55 & 0.66 & 1.69 & 1.80 & 0.76 \\
\hline $\mathrm{D}_{4}$ & 24.02 & 12.10 & 0.99 & 2.61 & 3.01 & 1.35 \\
\hline
\end{tabular}

Table 4: Main results obtained for strengthened beam B2 by static bending tests.

* Curvature evaluated from deformation on compressive edge and GFRP bar.

In terms of fracture's propagation, a condition like the previous one occurs during the test, as shown in Fig. 13. After attaining a load value of $\mathrm{Pu}=38.40 \mathrm{kN}$, the specimen $\mathrm{B} 2$ collapses, resulting in the crushing of compressed concrete and total debonding of the NSM GFRP rod. The strengthening's debonding interested the portion of beam from the midspan section to the end section, leading the detachment of the concrete cover. 

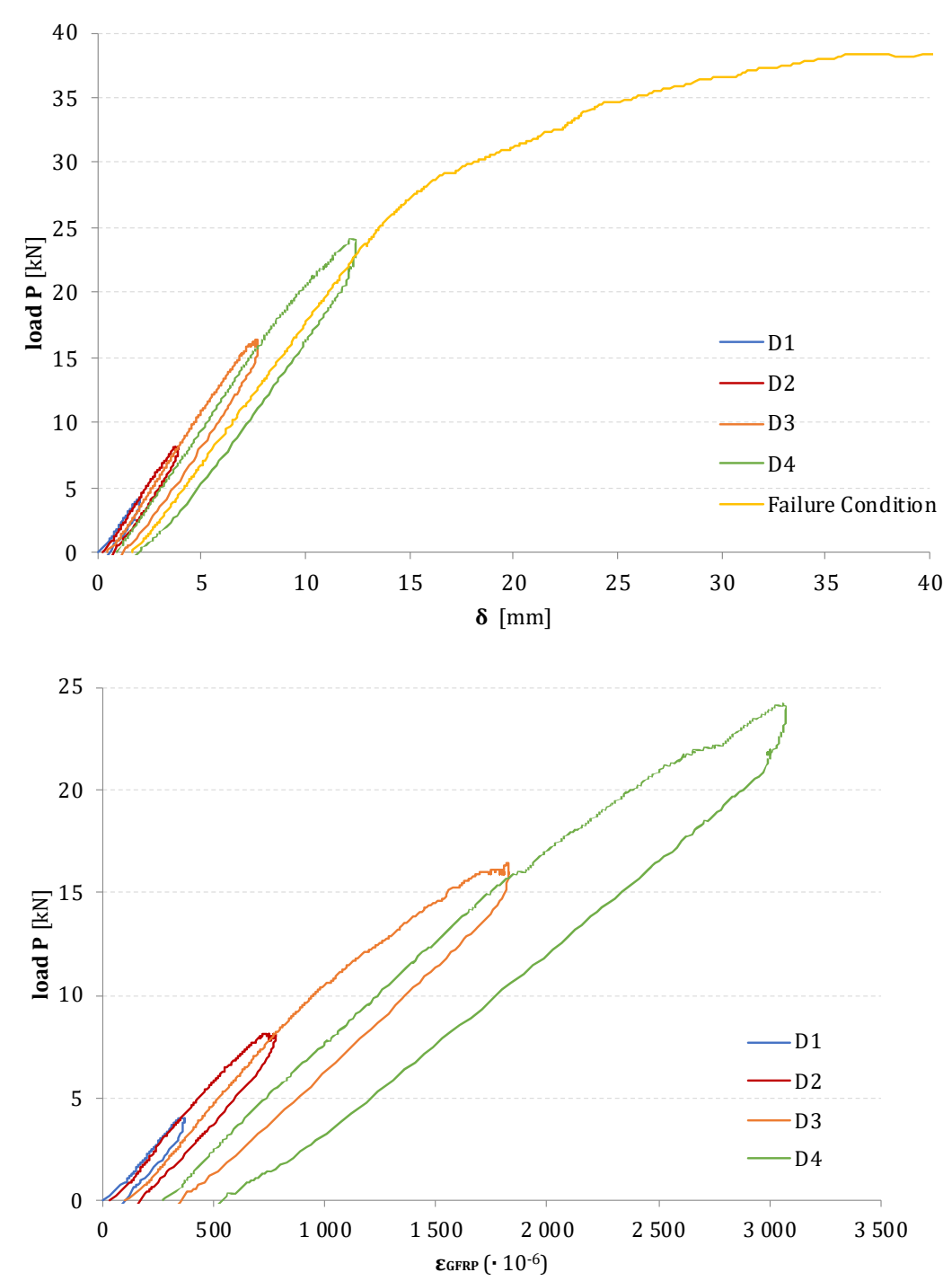

(a)

(b)

Figure 11: Diagrams (a) load, P, vs deflection, $\delta$, and (b) load, P, vs strain of GFRP rod, $\varepsilon_{\mathrm{GFRP}}-$ RC beam B2 strengthened with NSM GFRP rod

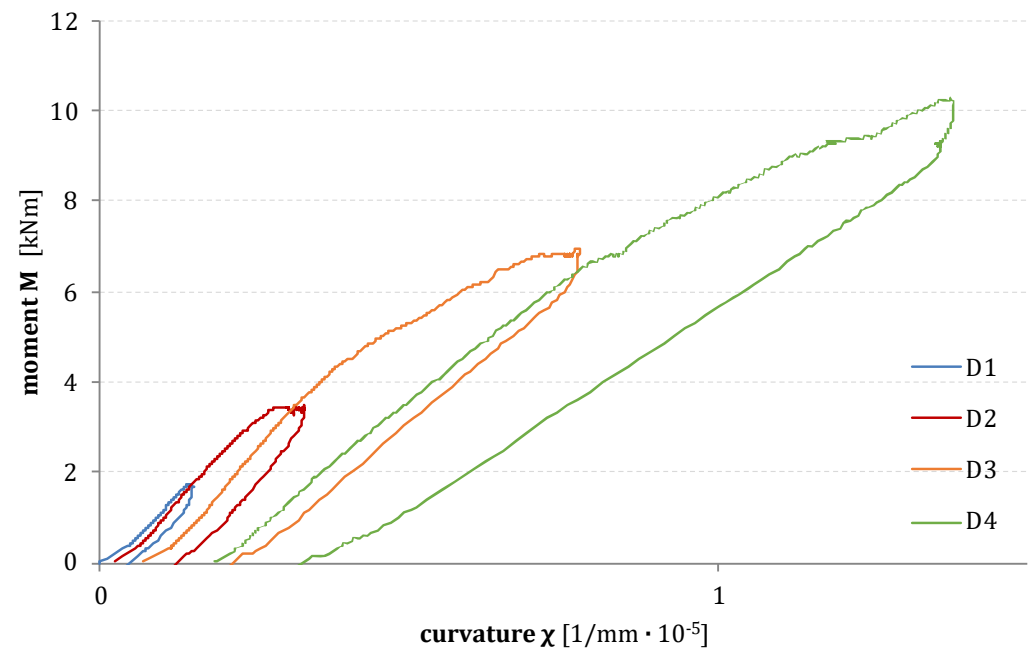

Figure 12: Diagram moment, M, vs curvature, $\chi$, at the midspan section - RC beam B2 strengthened with NSM GFRP rod. 


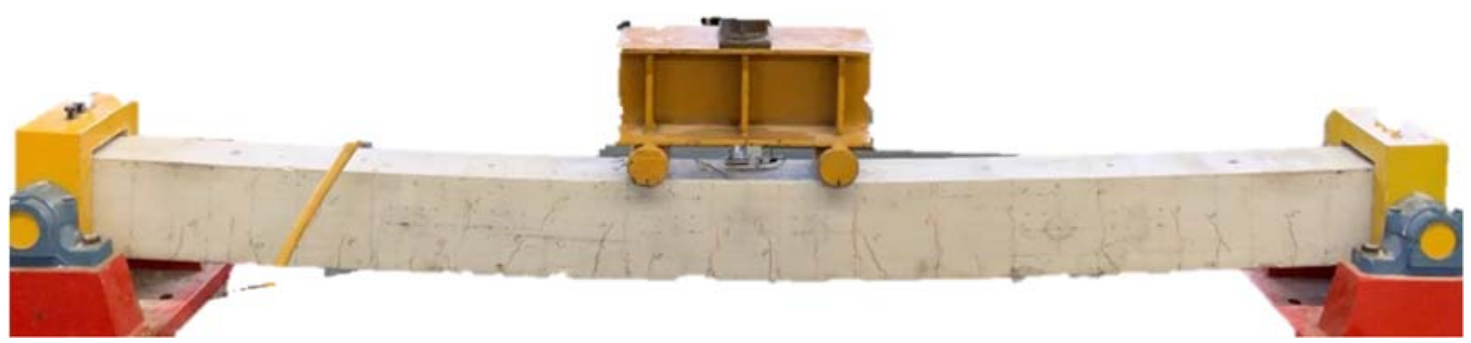

Figure 13: Visualization of cracks by bending loading at damage level $\mathrm{D}_{4}$ for $\mathrm{RC}$ beam $\mathrm{B} 2$ strengthened with NSM GFRP rod.

\section{DISCUSSIONS OF EXPERIMENTAL RESULTS}

7 his experimental research performed on RC beams strengthened with NSM CFRP and GFRP rod permits the highlighting of numerous aspects that could be helpful in the civil applications for the structural repair of damaged elements.

The effectiveness of the Near Surface Mounted approach is the first outcome that should be highlighted. This technique allows for beams to be strengthened until their collapse under bending, preserving the FRP rods' connection without any separation. The strengthened elements reached failure for the attaining of the ultimate strain of compressive concrete. An improvement in the rigidity capacity of RC beams with NSM CFRP and GFRP during bending tests was verified. If we examine the load versus deflection experimental diagrams for the models with strengthening, it can be seen how ductility and ample deflections typify the response of strengthened elements until failure condition. In Fig. 14 the behavior of two beams under bending loading cycles until failure are compared. We can see that the strengthening of beams with FRP rod is adequate for both beams. Stiffnesses of beams B2 is lower than that of beam B1 and this is a direct result of the mechanical properties of the strengthening bar of CFRP respect to GFRP rod being the Young's modulus of GFRP is much lower than that of the CFRP while the area of section is almost equal between CFRP and GFRP rods. This result is also reflected on the ultimate capacity in terms of load $\mathrm{P}_{\mathrm{u}}$ which is minor of $30 \%$ for the beam strengthened with GFRP rod.

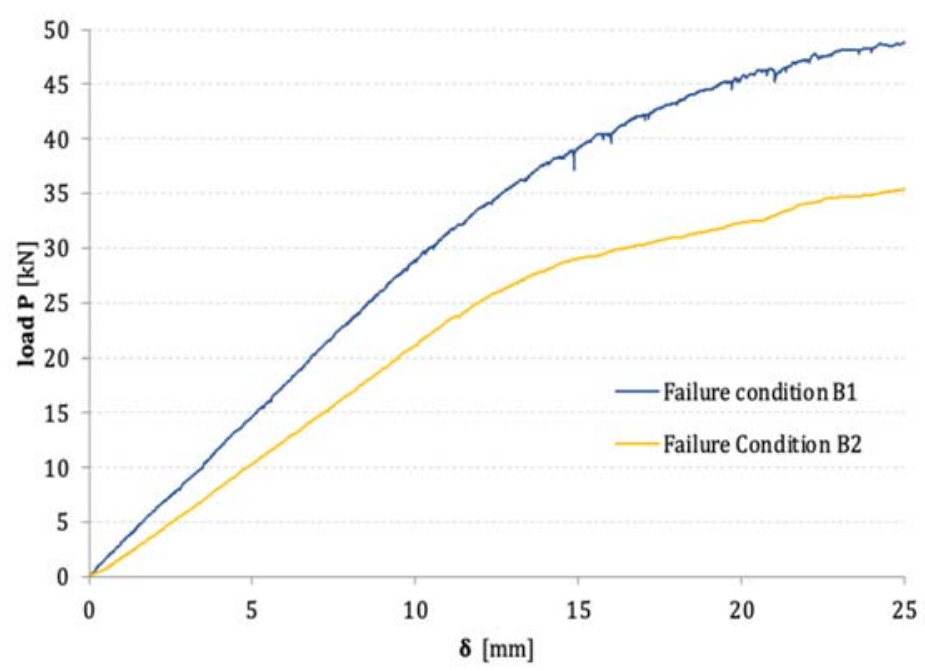

Figure 14: Diagrams load, P, vs deflection, $\delta$ for strengthened beams B1 and B2 until failure.

Moreover, another important aspect emerging from experimental campaign, is the impossibility to apply the Bernoulli's hypothesis in the study of RC sections of beams strengthened with NSM FRP rod; this is due to the presence, under bending, of a FRP stress-strain lag that which makes it impossible to consider the section as plane. The entity of strain collected at the midspan section at damage degree $\mathrm{D}_{\mathrm{i}}$ has been diagrammed and depicted, respectively, for the un-strengthened beam B1, 
in Fig. 15, for the NSM CFRP strengthened beam B1, in Fig. 16 and for the NSM GFRP strengthened beam B2, in Fig. 17. The measurement of strains obtained for the edge of compressive concrete and at the level of steel bars underlines the maintaining of plane section in the case of un-strengthened RC beam B1 (Fig. 15). In Fig. 16 the point of compressive edge of concrete, tensile steel and tensile CFRP rod is considered for beam B1 strengthened with CFRP rod. In this case, it is noted the non-linear distribution of strains through the full depth of the beam; in particular, the strains on the CFRP rod aren't linearly congruent with the strains of steel and of the compressed concrete fiber and are affected by a stress-strain lag. It means that the hypothesis of preserving the planarity of the bending section isn't satisfied. Also, in the case of beam B2 the non-planarity of section appears at midspan since the first load cycle D1=4kN, as Fig. 17 shows.

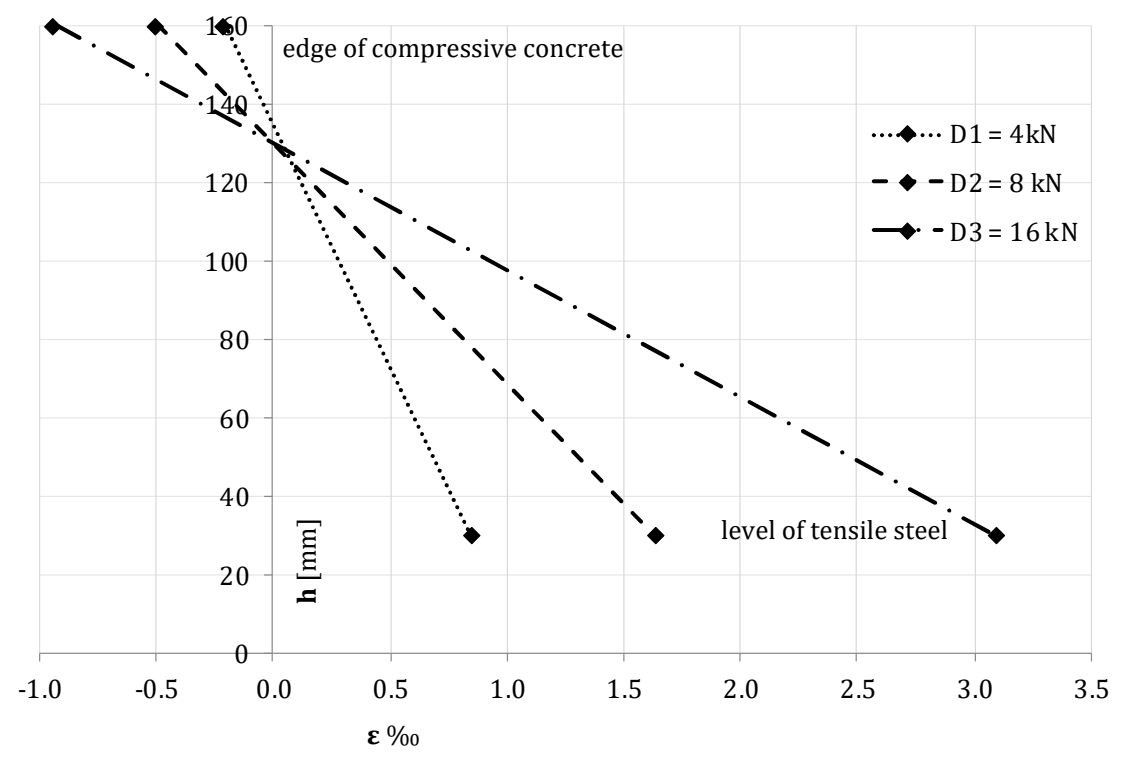

Figure 15: Distribution of strain at mid length cross section at $\mathrm{D}_{\mathrm{i}}$, with $\mathrm{i}=1,2,3$ - un-strengthened beam $\mathrm{B} 1$.

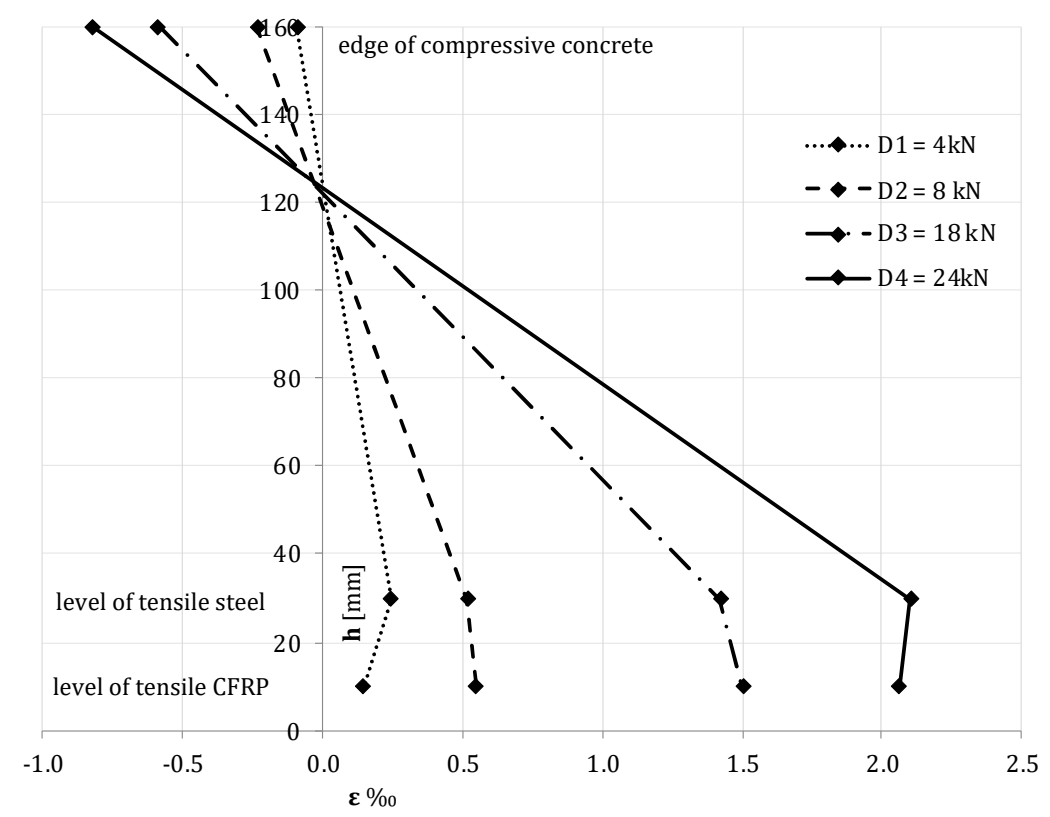

Figure 16: Distribution of strain at mid length cross section at $\mathrm{D}_{\mathrm{i}}$, with $\mathrm{i}=1,2,3$ - beam $\mathrm{B} 1$ with NSM CFRP rod. 


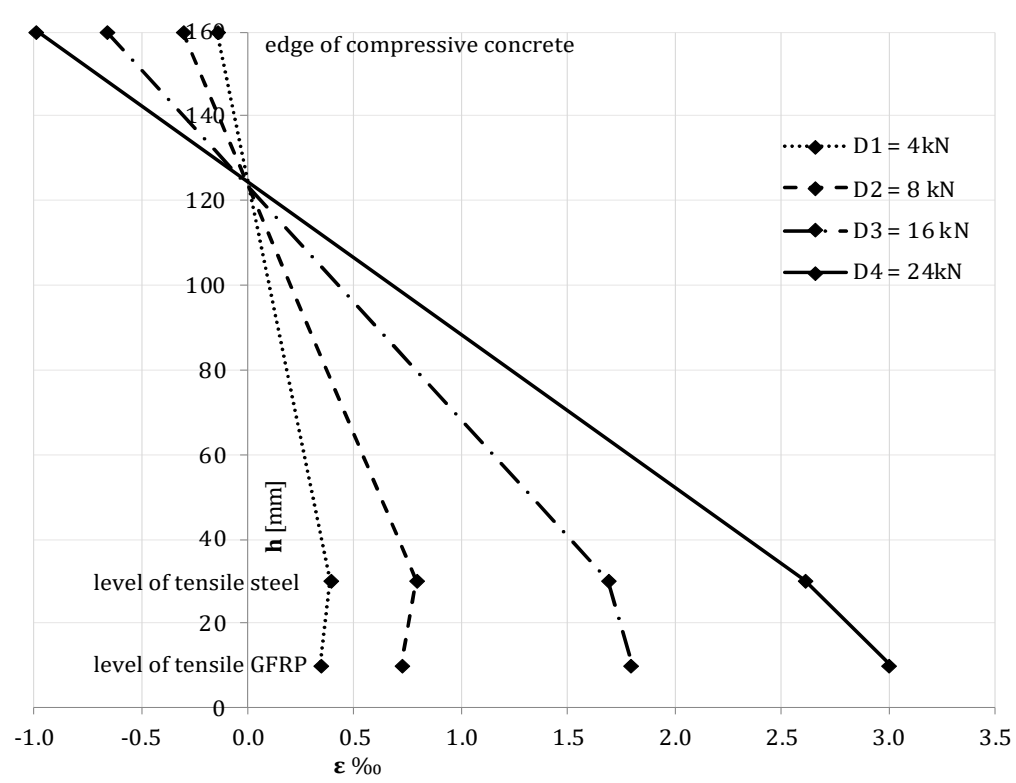

Figure 17: Distribution of strain at mid length cross section at $\mathrm{D}_{\mathrm{i}}$, with $\mathrm{i}=1,2,3$ - beam $\mathrm{B} 2$ with NSM GFRP rod.

The entity of stress-strain lag can be estimate considering the ratios (1) and (2) (Tab. 5), where $\varepsilon_{F R P}$ is the strain that CFRP and GFRP rod should exhibits if the Bernoulli's plane section hypothesizes is verified. The calculus of $k_{1}$ and $k_{2}$ coefficients was made both for the strengthened RC beams B1 and B2, considering the levels of damage $\mathrm{D}_{1}$ to $\mathrm{D}_{4}$ thus until values of steel strain greater than yield strain of steel. It can be observed that the average values $k_{1 \text {,av }} \cong 0.93 \div 0.99$ and $k_{2, \text { av }} \cong 0.24$ $\div 0.18$ (respectively for B1 and B2), are quite different and lead to results more or less conservative. Nevertheless, in the study of the behaviour of RC section with the presence of NSM FRP rods, it can be a good strategy the adoption of one of the coefficient $k_{1, \text { av }}\left(\right.$ or $k_{2, \text { av }}$ ) to prevent overestimation of the beam's strength.

$$
\begin{aligned}
& \mathrm{k}_{1}=\frac{\varepsilon_{\mathrm{FRP}}}{\varepsilon_{\mathrm{s}}} \\
& \mathrm{k}_{2}=\frac{\varepsilon_{\mathrm{FRP}}^{*}-\varepsilon_{\mathrm{FRP}}}{\varepsilon_{\mathrm{FRP}}^{*}}
\end{aligned}
$$

\begin{tabular}{ccccc}
\hline RC beams & $\begin{array}{c}\text { Damage } \\
\text { steps }\end{array}$ & $\begin{array}{c}\text { Load, P } \\
{[\mathrm{kN}]}\end{array}$ & $\begin{array}{c}k_{1}= \\
\varepsilon_{\mathrm{FRP}} / \varepsilon_{\mathrm{s}}\end{array}$ & $\begin{array}{c}k_{2}= \\
\varepsilon^{*}{ }_{\mathrm{FRP}}-\varepsilon_{\mathrm{FRP}} \\
/ \varepsilon^{*}{ }_{\mathrm{FRP}}\end{array}$ \\
& $\mathrm{D}_{1}$ & 4.00 & 0.60 & 0.51 \\
$\mathrm{~B} 1$ & $\mathrm{D}_{2}$ & 8.00 & 1.06 & 0.13 \\
& $\mathrm{D}_{3}$ & 18.00 & 1.06 & 0.13 \\
& $\mathrm{D}_{4}$ & 24.00 & 0.98 & 0.19 \\
& $\mathrm{D}_{1}$ & 4.00 & 0.87 & 0.28 \\
& $\mathrm{D}_{2}$ & 8.00 & 0.91 & 0.25 \\
& $\mathrm{D}_{3}$ & 16.00 & 1.07 & 0.12 \\
& $\mathrm{D}_{4}$ & 24.00 & 1.15 & 0.05 \\
\hline
\end{tabular}

Table 5: Lag coefficients $k$. 


\section{CONCLUSIONS}

7 he following are the main outcomes derived from this experimental study on the behaviour of RC beams strengthened with CFRP and GFRP rods using the near-surface method:

1 1. The NSM approach proves to be adequate, both for CFRP and GFRP rods, with no loss of the concrete cover's bond up to collaps under bending.

2. The ultimate phase of RC beams strengthened was characterized by loss of strength of compressive concrete without detachment of cover.

3. The adoption of FRP rod seems to be suitable; the performance of a RC beam with FRP strengthening is highly reliant on the properties of the FRP itself.

4. The Bernoulli's hypothesis of planarity of sections is not valid for sections with FRP rods and the calculus of sections must follow a non-linear development until ultimate state.

\section{ACKNOWLEDGEMENT}

7 he Polytechnic University of Marche supplied research funds to enable this experimental study. The authors would like to thank all the technicians and students who assisted in the development of this research work.

\section{REFERENCES}

[1] De Lorenzis L., Nanni A., La Tegola A. Flexural and shear strengthening of reinforced concrete structures with near surface mounted FRP rods. Proc. Third Int. Conf. Advanced Composite Materials in Bridges and Structures, Ottawa (Canada); 2000. pp.521-528.

[2] Teng JG, Chen JF, Smith ST, Lam L. FRP-strengthened RC structures. West Sussex: Wiley; 2002.

[3] Lu, X.Z., Teng, J.G., Ye, L.P., Jiang, J.J.: Bond-slip models for FRP sheets/plates bonded to concrete, Engineering Structures, 27(6), pp. 920-937 (2005).

[4] Kotynia R. Analysis of the flexural response of NSM FRP-strengthened concrete beams. Proc. of the Eight Int. Conf.on Fibre-Reinforced Plastics for Reinforced Concrete Structures, Patrasso (Grecia); 2007

[5] Bilotta A, Ceroni F, Nigro E, Pecce M. Efficiency of CFRP NSM strips and EBR plates for flexural strengthening of RC beams and loading pattern influence. Compos Struct 2015; 124:163e75.

[6] De Lorenzis, L., Teng, J.G.: Near-Surface mounted FRP reinforcement: an emerging technique for strengthening structures, Composites Part B: Engineering, 38(2), pp. 119-143 (2007).

[7] De Lorenzis, L., Nanni, A.: Bond between near surface mounted fiber reinforced polymer rods and concrete in structural strengthening. ACI Structural Journal, 99(2), pp. 123-133 (2002).

[8] De Lorenzis, L., Nanni, A.: Shear strengthening of reinforced concrete beams with NSM fibre-reinforced polymer rods. ACI Struct. J., 98(1), pp. 60-8 (2001).

[9] El-Hacha, R., Rizkalla, S.: Near-surface mounted fibre reinforced polymer reinforcements for flexural strengthening of concrete structures. ACI Structural Journal, 101(5), pp. 717-726 (2004).

[10] Capozucca, R.: On the strengthening of RC beams with near surface mounted GFRP rods. Composite Structures, 117C, pp: 143-155 (2014).

[11] Cosenza, E., Manfredi, G., Realfonzo, R.: Behavior and modeling of bond of FRP rebars to concrete, ASCE Journal of Composites for Construction, 1(2), pp. 40-51 (1997).

[12] Hassan, T.K., Rizkalla, S.: Bond mechanism of NSM FRP for flexural strengthening of concrete structures, ACI Structural Journal, 101(6), pp. 830-839, (2004).

[13] Hassan, T., Rizkalla, S.: Investigation of bond in concrete structures strengthened with near-surface mounted carbon fibre reinforced polymer strips. J. of Comp. for Constr., 7(3) (2003)

[14] Sena Cruz, J.M., Barros, J.A.O., Gettu, R., Azevedo, A.F.M.: Bond behavior of near-surface mounted CFRP laminate strips under monotonic and cyclic loading. ASCE, Journal of Composites for Construction, 10, pp. 295-303 (2006).

[15] Coelho MRF, Sena-Cruz JM, Neves LAC. A review on the bond behavior of FRP NSM systems in concrete. Constr Build Mater 2015; 93:1157e69. 
[16] Blaschko M. Bond behaviour of CFRP strips glued into slits. In: Proceedings FRPRCS-6. Singapore: World Scientific, pp: 205-14 (2003).

[17] Capozucca, R.: Analysis of bond-slip effects in RC beams strengthened with NSM CFRP rods. Composite Structures, 102, pp. 110-123 (2013).

[18] Ceroni F, Pecce M, Bilotta A, Nigro E. Bond behavior of FRP NSM systems in concrete elements. Compos Part BEngineering 2012;43(2):99e109.

[19] Capozucca, R.: Static and dynamic response of damaged RC beams strengthened with NSM CFRP rods, Composite Structures 91(3), 237-248 (2009).

[20] Capozucca, R., Bossoletti, S., Montecchiani, S. Assessment of RC beams with NSM CFRP rectangular rods damaged by notches. Composite Structures, 128, pp. 322-341 (2015).

[21] Capozucca, R.,Vibration analysis of damaged RC beams strengthened with GFRP. Composite Structures, 200, pp. 624634 (2018)

[22] Capozucca, R., Bossoletti, S., Static and free vibration analysis of RC beams with NSM CFRP rectangular rods. Composites Part B: Engineering, 67, pp. 95-110 (2014)

[23] Perera, K., Ibell, T., Darby, A., Denton, S.: Bond mechanisms of various shapes of NSM CFRP bars. In: 4th International Conference on Advanced Composites in Construction, (ACIC 09), pp. 250-257, Edinburgh (2009).

[24] Yost JR, Gross SP, Dinehart DW, Mildenberg JJ. Flexural behavior of concrete beams strengthened with near-surface mounted CFRP strips. ACI Struct J 2007;104(4):430e7.

[25] Sharaky, I.A., Torres, L., Baena, M., Miàs, C.: An experimental study of different factors affecting the bond of NSM FRP bars in concrete. Composite Structures, 99, pp. 350-365 (2013).

[26] Teng JG, Zhang SS, Chen JF. Strength model for end cover separation Failure in RC beams strengthened with nearsurface mounted (NSM) FRP strips. Eng Struct 2016; 110:222e32.

[27] Nanni, A., Di Ludovico, M., Parretti, R. Shear Strengthening of a PC Bridge Girder with NSM CFRP Rectangular Bars. Advances in Structural Engineering, 7(4), pp. 297-309 (2004)

[28] Ding, Y., Ning, X., Zhang, Y., Pacheco-Torgal, F., Aguiar, J.B.: Fibres for enhancing of the bond capacity between GFRP rebar and concrete. Construction and Building Materials, 51, pp: 303-312 (2014).

[29] Masmoudi, A., Ouezdou, M., Ben, Bouaziz J.: New parameter design of GFRP RC beams. Construction and Building Materials, 29, pp. 627-632 (2012)

[30] C. Sabau, C. Popescu, G. Sas, J.W. Schmidt, T. Blanksvärd, B. Täljsten, Strengthening of RC beams using bottom and side NSM reinforcement, Compos. B Eng. 149 (2018) 82-91

[31] ACI 440 1R-15. Guide for the design and construction of structural concrete reinforced with FRP bars. Farmington Hills, MI: American Concrete Institute (ACI); 2007.

[32] ASTM D 3039/D 3039 M - 08. Standard Test Method for Tensile Properties of Polymer Matrix Composite Materials. American Standard of Testing and Materials, 2008. 